\title{
Synthesis, Spectroscopic Characterization and Biological Activities of Transition Metal Complexes Derived from a Tridentate Schiff Base
}

\author{
J. Senthil Kumaran, S. Priya, N. Jayachandramani, and S. Mahalakshmi \\ PG \& Research Department of Chemistry, Pachaiyappa’s College, University of Madras, Chennai, Tamil Nadu 600 030, India \\ Correspondence should be addressed to S. Mahalakshmi; drsmaha.chem@gmail.com
}

Received 5 January 2012; Revised 31 May 2012; Accepted 1 June 2012

Academic Editor: Theocharis C. Stamatatos

Copyright (C) 2013 J. Senthil Kumaran et al. This is an open access article distributed under the Creative Commons Attribution License, which permits unrestricted use, distribution, and reproduction in any medium, provided the original work is properly cited.

A new series of $\mathrm{Cu}$ (II), Ni (II), Co (II) and $\mathrm{Zn}$ (II) complexes have been synthesized from the Schiff base derived from 4-hydroxy3-methoxybenzylidine-4-aminoantipyrine and 2-aminophenol. The structural features have been determined from their elemental analysis, magnetic susceptibility, molar conductance, Mass, IR, UV-Vis, ${ }^{1} \mathrm{H}-\mathrm{NMR},{ }^{13} \mathrm{C}-\mathrm{NMR}$ and ESR spectral studies. The redox behavior of the copper complex has been studied by cyclic voltammetry. The data confirm that the complexes have composition of $\mathrm{ML}_{2}$ type. The electronic absorption spectral data of the complexes propose an octahedral geometry around the central metal ion. All the metal complexes with DNA structure were guided by the presence of inter-molecular $\mathrm{C}-\mathrm{H} \cdots \mathrm{O}$ and $\mathrm{C}-\mathrm{H} \cdots \mathrm{N}$ hydrogen bonds. The biological activity of the synthesized compounds were tested against the bacterial species such as Bacillus subtilis, Staphylococcus aureus, Proteus vulgaris and fungal species such as Candida albicans by the well-diffusion method.

\section{Introduction}

Schiff bases are regarded as "privileged ligands" due to their ability to form complexes with a wide range of transition metal ions yielding stable and strongly colored metal complexes. Some of them have been shown to reveal attractive physical, chemical properties and potential biological activities $[1,2]$. In azomethine derivatives, the $\mathrm{C}=\mathrm{N}$ linkage is essential for biological activity; several azomethines were reported to possess important antibacterial [35], antifungal [6,7], anticancer [8], and diuretic activities [9]. With the rising occurrence of deep mycosis, there has been increasing emphasis on the screening of new and more effective antimicrobial drugs with low toxicity. Schiff bases and their complexes were recently established to have significant antitumor and biological activity $[10,11]$. In recent years, a great deal of interest in the transition metal complexes of 4-aminoantipyrine and its derivatives have been extensively examined due to their diverse biological properties as antifungal, antibacterial [12], analgesic, sedative, antipyretic, anti-inflammatory [13], anticonvulsant agents [14] and greater DNA binding ability [15]. This prompted us to synthesize a novel series of heterocyclic Schiff bases containing the antipyrinyl moiety. The present study reports the synthesis, characterization, and antimicrobial studies of transition metal complexes containing tridentate Schiff base derived from 4-hydroxy-3-methoxybenzylidine4 -aminoantipyrine and 2-aminophenol. The structure of the complexes is elucidated using elemental analyses, magnetic moment, Mass, IR, ${ }^{1} \mathrm{H}-\mathrm{NMR},{ }^{13} \mathrm{C}-\mathrm{NMR}$, ESR and molar conductance. The biological activity of the Schiff base and their metal complexes is reported.

\section{Experimental}

2.1. Materials and Methods. 4-Aminoantipyrine, 4-hydroxy3-methoxybenzaldehyde and 2-aminophenol were obtained from Sigma. Metal chlorides were purchased from Merck. All chemicals used were of AR grade. Solvents were purified and distilled before use. Molar conductivity was determined using Systronic Conductivity Bridge with a dip type cell using freshly prepared $10^{-3} \mathrm{M}$ solutions in DMSO at RT. The IR spectra were recorded in $\mathrm{KBr}$ pellet on a Perkin-Elmer 
<smiles>COc1cc(/C=N/c2c(C)n(C)n(-c3ccccc3)c2=O)ccc1O</smiles>

Step 2

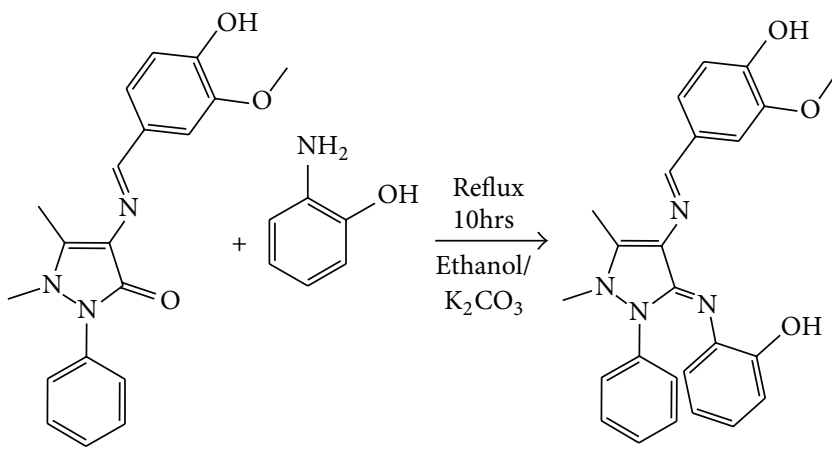

SCHEme 1: Schematic route for the synthesis of Schiff base ligand (HL).

783 spectrometer in the range $4000-400 \mathrm{~cm}^{-1}$. UV-Visible spectra of the complexes were recorded on Perkin Elmer Lambda EZ201 spectrophotometer in DMSO solution. ${ }^{1} \mathrm{H}$ NMR spectra was recorded on a JEOL FX-90X instrument using $\mathrm{CDCl}_{3}$ as a solvent and TMS as an internal standard. The RT magnetic measurements were carried out using Guoy balance and the diamagnetic corrections were made using Pascal's constant.

2.2. Synthesis of Schiff base Ligand (HL). 4-hydroxy-3methoxybenzylidine-4-aminoantipyrine was prepared by the condensation of 4-hydroxy-3-methoxybenzaldehyde and 4-aminoantipyrine as reported earlier [16]. 4-hydroxy-3methoxybenzylidine-4-aminoantipyrine $(2 \mathrm{mmol})$ and 2 aminophenol $(2 \mathrm{mmol})$ were taken in ethanol $(50 \mathrm{~mL})$ solvent. To this mixture, $1 \mathrm{~g}$ of anhydrous potassium carbonate was added and then refluxed for $10 \mathrm{hrs}$. The resulting solution was concentrated on a water bath and allowed to cool at $0^{\circ} \mathrm{C}$ for $\sim 24 \mathrm{~h}$. The solid product formed was separated by filtration and washed thoroughly with $\mathrm{EtOH}$ and then dried in vacuum. (Yield: 64\%) (Scheme 1).

2.3. Synthesis of Metal (II) Complexes. A solution of metal (II) chloride $(2 \mathrm{mmol})$ in ethanol $(25 \mathrm{~mL})$ was stirred with an ethanolic solution $(50 \mathrm{~mL})$ of the Schiff base $(4 \mathrm{mmol})$. The above mixture was magnetically stirred for $2 \mathrm{~h}$. Then the solution was reduced to one-third on a water bath. The solid complex precipitated was filtered off and washed thoroughly with ethanol and dried in vacuo.

2.4. In Silico Studies on DNA and Metal Complexes. On the basis of literature evidences $[17,18]$, we have selected the DNA sequence and it was subjected into DNA sequence to structure web server [19] for generating the threedimensional structure of DNA based on experimental fiberdiffraction studies [20]. The structure of metal complexes was drawn using ChemDraw Ultra10.0 program [21] and threedimensional structure of metal complexes was prepared by using Discovery studio 3.1 [22]. The DNA-metal complex interaction was studied using Patch dock web server [23]. The PyMol stand-alone program [24] was used to visualize the interaction between DNA Structure and metal complexes. HBAT [25], hydrogen bond analysis tool was used to analyze the strong and weak hydrogen bonds present between DNA and metal complexes. In this in-house developed program, the standard hydrogen bond distance $(\mathrm{H} \cdots \mathrm{A})$ and angle $(\mathrm{X}$ $\mathrm{H} \cdots \mathrm{A}$ ) was set as $2.8 \AA$ and $90^{\circ}$, respectively.

2.5. Biological Activity. The biological activities of synthesized Schiff Base and its $\mathrm{Cu}$ (II), Co (II), Ni (II) and $\mathrm{Zn}$ (II) complexes have been studied for their antibacterial and antifungal activities by well diffusion test using MuellerHinton Agar (MHA) and Sabouraud Dextrose Agar (SDA). The antibacterial and antifungal activities were done at $60 \mu \mathrm{g} / \mathrm{mL}$ concentrations in DMF solvent using bacteria ( $S$. aureus, B. subtilis, and P. vulgaris) and fungi (C. albicans) at the minimum inhibitory concentration (MIC) method. These bacterial strains were incubated for $24 \mathrm{~h}$ at $37^{\circ} \mathrm{C}$ and fungi strains were incubated for $48 \mathrm{~h}$ at $37^{\circ} \mathrm{C}$. Standard antibacterial (tetracycline) and antifungal drug (amphotericin) was used for comparison under similar conditions. Activity was determined by measuring the diameter of the zone showing complete inhibition ( $\mathrm{mm})$.

\section{Results and Discussion}

3.1. Characterization of Schiff Base Ligand. The analytical data for the ligand and their complexes together with some physical properties are summarized in Table 1 . The magnetic susceptibilities of the complexes at room temperature are consistent with octahedral geometry around the central metal ion. The low conductance of the complexes supports the nonelectrolytic nature of the metal complexes.

3.2. Mass Spectra. Mass spectra provide an essential clue for elucidating the structure of compounds. The ESI mass spectra of the ligand and its copper complex were recorded and used to compare their stoichiometry composition. The Schiff base displays the prominent molecular ion peak $\left(\mathrm{M}^{+}\right)$at $m / z=$ 428 and weak isotopic peak at $\left(\mathrm{M}^{+}+1\right) \mathrm{m} / z=429$ (Figure 1). The base peak appears at $\mathrm{m} / z=200$ corresponding to $\left[\mathrm{C}_{11} \mathrm{H}_{12} \mathrm{~N}_{4}\right]^{+}$. The other fragments give the peaks at 136,93 and 77 . The mass spectrum of copper complex shows the molecular ion peak at $m / z=923$ due to $\left(\mathrm{CuC}_{50} \mathrm{H}_{46} \mathrm{~N}_{8} \mathrm{O}_{6}\right)^{+}$ (Figure 2). The complex underwent demetallation to form 
TABLE 1: Physical and analytical data of the synthesized Schiff base and its complexes.

\begin{tabular}{|c|c|c|c|c|c|c|c|c|c|c|}
\hline \multirow{2}{*}{ Compound } & \multirow{2}{*}{$\begin{array}{l}\text { Empirical } \\
\text { formula }\end{array}$} & \multirow{2}{*}{$\begin{array}{l}\text { Yield } \\
(\%)\end{array}$} & \multirow{2}{*}{ Colour } & \multicolumn{4}{|c|}{ Found (Calcd) (\%) } & \multirow{2}{*}{$\begin{array}{c}\text { Formula } \\
\text { weight }\end{array}$} & \multirow{2}{*}{$\begin{array}{c}(\lambda \mathrm{M}) \\
\mathrm{Ohm}^{-1} \mathrm{~cm}^{2} \\
\mathrm{~mol}^{-1} \times 10^{-3}\end{array}$} & \multirow[t]{2}{*}{$\mu_{\mathrm{eff}}$ (B.M.) } \\
\hline & & & & M & $\mathrm{C}$ & $\mathrm{H}$ & $\mathrm{N}$ & & & \\
\hline $\mathrm{HL}$ & $\mathrm{C}_{25} \mathrm{H}_{24} \mathrm{~N}_{4} \mathrm{O}_{3}$ & 64 & Brown & - & $\begin{array}{c}69.97 \\
(70.08)\end{array}$ & $\begin{array}{c}5.21 \\
(5.64)\end{array}$ & $\begin{array}{c}12.95 \\
(13.07)\end{array}$ & 428.4 & - & - \\
\hline $\mathrm{CuL}_{2}$ & $\mathrm{CuC}_{50} \mathrm{H}_{46} \mathrm{~N}_{8} \mathrm{O}_{6}$ & 58 & Dark Brown & $\begin{array}{c}6.76 \\
(6.88)\end{array}$ & $\begin{array}{c}64.89 \\
(65.02)\end{array}$ & $\begin{array}{c}5.14 \\
(5.02)\end{array}$ & $\begin{array}{c}12.02 \\
(12.13)\end{array}$ & 923.1 & 2.6 & 1.88 \\
\hline $\mathrm{NiL}_{2}$ & $\mathrm{NiC}_{50} \mathrm{H}_{46} \mathrm{~N}_{8} \mathrm{O}_{6}$ & 56 & Brown & $\begin{array}{c}6.07 \\
(6.45)\end{array}$ & $\begin{array}{c}65.42 \\
(65.70)\end{array}$ & $\begin{array}{c}4.87 \\
(5.07)\end{array}$ & $\begin{array}{c}12.12 \\
(12.26)\end{array}$ & 913.5 & 1.6 & 2.97 \\
\hline $\mathrm{CoL}_{2}$ & $\mathrm{CoC}_{50} \mathrm{H}_{46} \mathrm{~N}_{8} \mathrm{O}_{6}$ & 62 & Red & $\begin{array}{c}6.14 \\
(6.42)\end{array}$ & $\begin{array}{c}65.35 \\
(65.72)\end{array}$ & $\begin{array}{c}4.75 \\
(5.07)\end{array}$ & $\begin{array}{c}12.05 \\
(12.26)\end{array}$ & 913.3 & 1.9 & 4.38 \\
\hline $\mathrm{ZnL}_{2}$ & $\mathrm{ZnC}_{50} \mathrm{H}_{46} \mathrm{~N}_{8} \mathrm{O}_{6}$ & 56 & Yellow & $\begin{array}{c}7.10 \\
(7.22)\end{array}$ & $\begin{array}{c}65.20 \\
(65.42)\end{array}$ & $\begin{array}{c}4.99 \\
(4.85)\end{array}$ & $\begin{array}{c}12.17 \\
(12.31)\end{array}$ & 920.2 & 1.8 & Diamagnetic \\
\hline
\end{tabular}

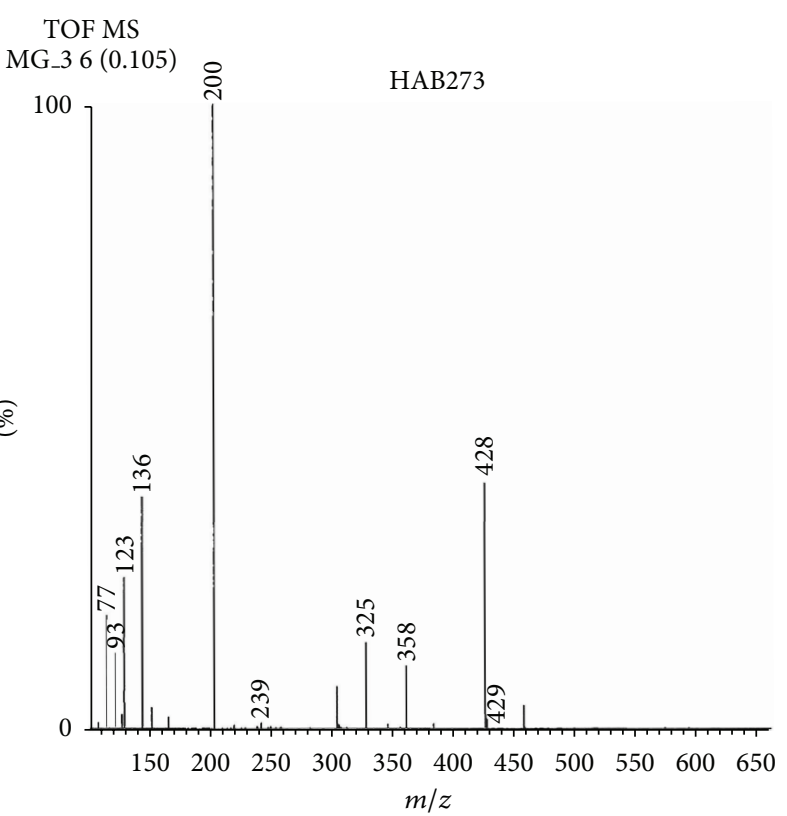

Figure 1: Mass spectrum of Schiff Base Ligand (HL).

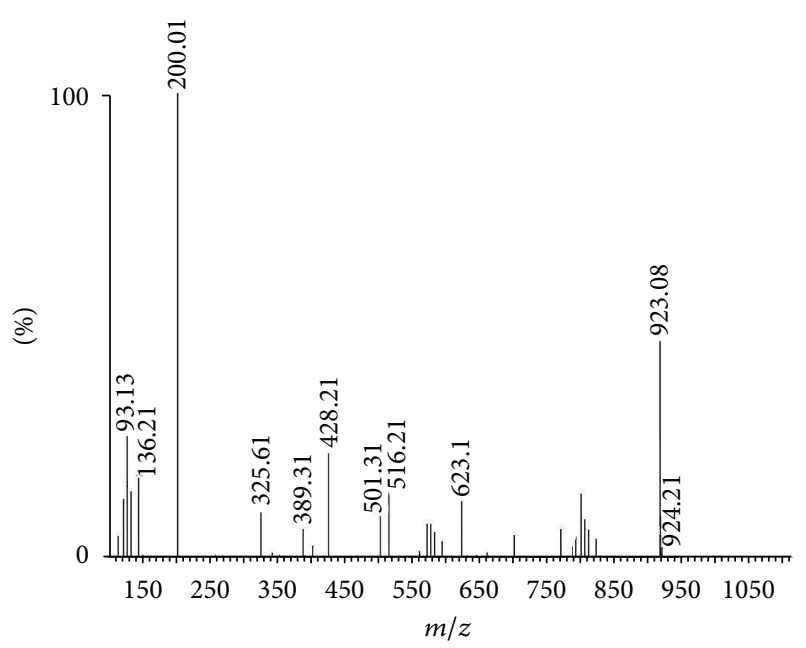

Figure 2: Mass spectrum of the $\mathrm{CuL}_{2}$ complex.

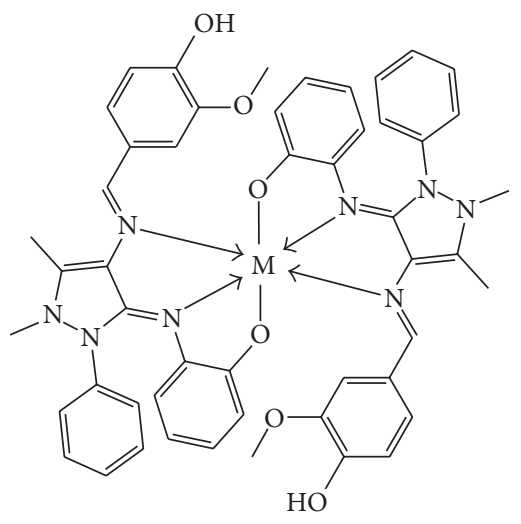

Scheme 2: $\mathrm{M}=\mathrm{Cu}$ (II), Ni (II), Co (II) and Zn (II).

the original molecular weight of the Schiff base ligand, gave fragment ion peak at $m / z=428$.

3.3. IR Spectra. The IR spectra of ligand shows a broad band for the $-\mathrm{OH}$ group at $3450-3050 \mathrm{~cm}^{-1}$. The absence of this peak in all the spectra of the complexes shows the deprotonation of the $-\mathrm{OH}$ group upon complexation. The spectrum of ligand shows the characteristic $-\mathrm{C}=\mathrm{N}$ bands in the region $1570-1510 \mathrm{~cm}^{-1}$, which are shifted to lower frequencies in the spectra of all the complexes $\left(1560-1490 \mathrm{~cm}^{-1}\right)$ representing the involvement of azomethine nitrogen in coordination to the metal ion [26-28]. Accordingly, the ligand acts as a tridentate chelating agent bonded to the metal ion via the two nitrogens $(-\mathrm{C}=\mathrm{N})$ and one phenolic oxygen atom (2aminophenol) of the Schiff base. Assignment of the proposed coordination sites is further supported by the appearance of medium bands at $510-500$ and $570-550 \mathrm{~cm}^{-1}$, which could be attributed to $v(\mathrm{M}-\mathrm{N})$ and $v(\mathrm{M}-\mathrm{O})$ respectively [29].

The proposed structure of the Schiff base complexes is shown in Scheme 2.

3.4. ${ }^{1} H$-NMR and ${ }^{13} C$-NMR Spectra. The ${ }^{1} \mathrm{H}$ NMR spectrum of ligand (HL) in $\mathrm{CDCl}_{3}$ provides the following signals: phenyl as multiplet at $6.91-7.49 \mathrm{ppm},=\mathrm{C}-\mathrm{CH}_{3}$ at $2.46 \mathrm{ppm}$, 


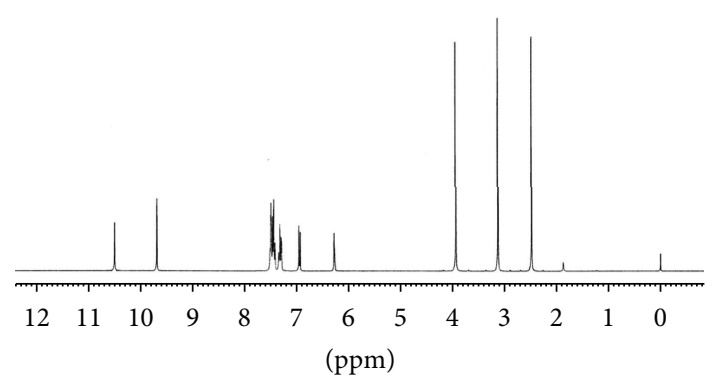

Figure 3: ${ }^{1} \mathrm{H}-\mathrm{NMR}$ spectrum of Schiff Base Ligand (HL).

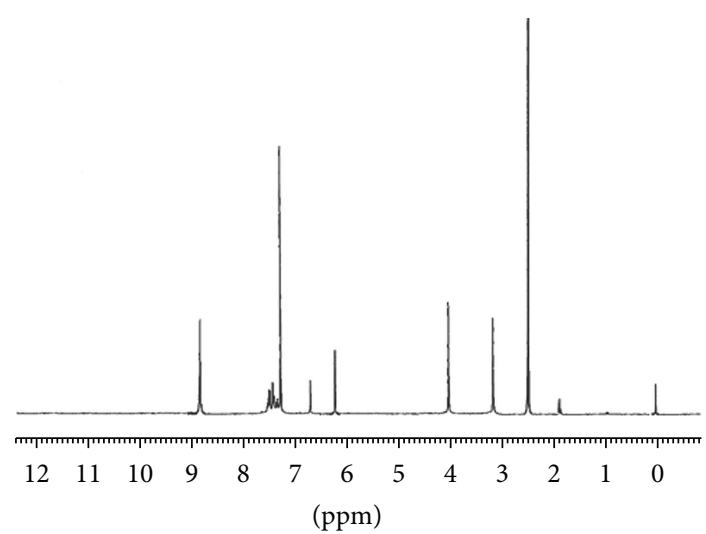

Figure 4: ${ }^{1} \mathrm{H}-\mathrm{NMR}$ spectrum of $\mathrm{ZnL}_{2}$.

$-\mathrm{N}-\mathrm{CH}_{3}$ at $3.11 \mathrm{ppm}, \mathrm{OH}-$ group in benzaldehyde moiety at $6.35 \mathrm{ppm}$ and $\mathrm{C}-\mathrm{CH}=\mathrm{N}-$ protons at $9.66 \mathrm{ppm}$. The peak at $10.52 \mathrm{ppm}$ is attributable to the phenolic -OH group present in the 2-aminophenol (Figure 3). The absence of this peak noted for the zinc complex proves the loss of the $-\mathrm{OH}$ proton due to complexation. The azomethine proton signal in the spectrum of the zinc complex is moved downfield compared to the free ligand, suggesting deshielding of the $>\mathrm{C}=\mathrm{N}$ group due to coordination with metal ion (Figure 4).

In the ${ }^{13} \mathrm{C}-\mathrm{NMR}$ spectrum (Figure 5), the azomethine carbon signal has appeared at $161 \mathrm{ppm}$. The pyrazolone ring carbon attached methyl carbon $\left(-\mathrm{CH}_{3}\right)$ and pyrazolone ring nitrogen attached methyl carbon $\left(>\mathrm{N}-\mathrm{CH}_{3}\right)$ peaks have been observed in the expected range at 10.2 and $35.9 \mathrm{ppm}$. In addition, the methoxy methyl carbon $\left(-\mathrm{O}-\mathrm{CH}_{3}\right)$ appears at $55.9 \mathrm{ppm}$. The aromatic carbon signals are seen at $108-157 \mathrm{ppm}$ range depending on their electronic environment.

3.5. Electronic Spectra. The electronic spectra can often give quick and dependable information about the ligand arrangements in the transition metal complexes. The UV-Vis spectrum of the copper complex shows three bands, which are assigned as an intraligand charge-transfer band $\left(25090 \mathrm{~cm}^{-1}\right)$, ligand-to-metal charge-transfer band $\left(23980 \mathrm{~cm}^{-1}\right)$ and a $d-d$ band $\left(15120 \mathrm{~cm}^{-1}\right)$ which is due to ${ }^{2} E_{g} \rightarrow{ }^{2} T_{2 g}$ transition. This $d-d$ band strongly favors an octahedral geometry around the metal ion. It is further supported by the magnetic susceptibility value $(1.88 \mu \mathrm{B})$. The nickel complex reveals three $d-d$ bands at 13305,15299 , and $23520 \mathrm{~cm}^{-1}$ which are assigned as ${ }^{3} A_{2 g} \rightarrow{ }^{3} T_{2 g}(F),{ }^{3} A_{2 g}$
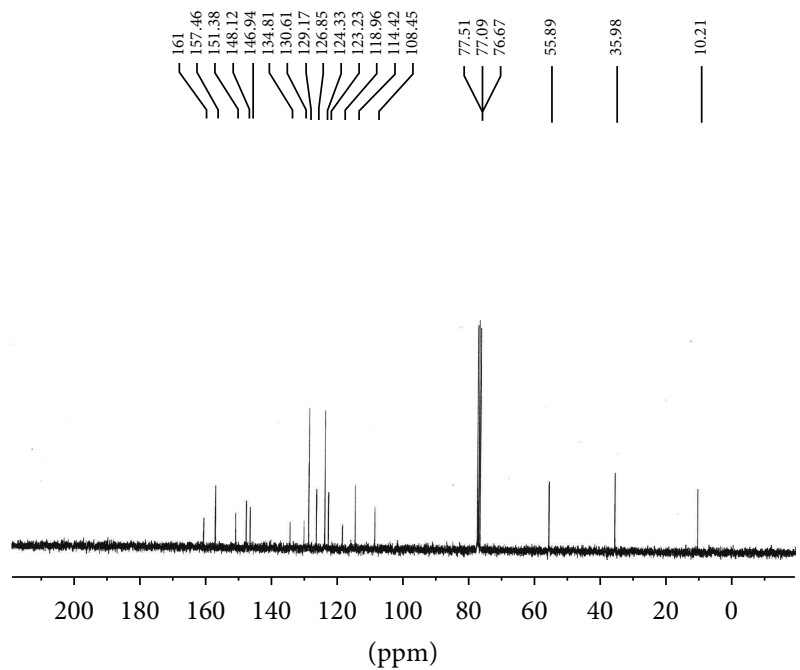

Figure 5: ${ }^{13} \mathrm{C}$-NMR spectrum of Schiff Base Ligand (HL).

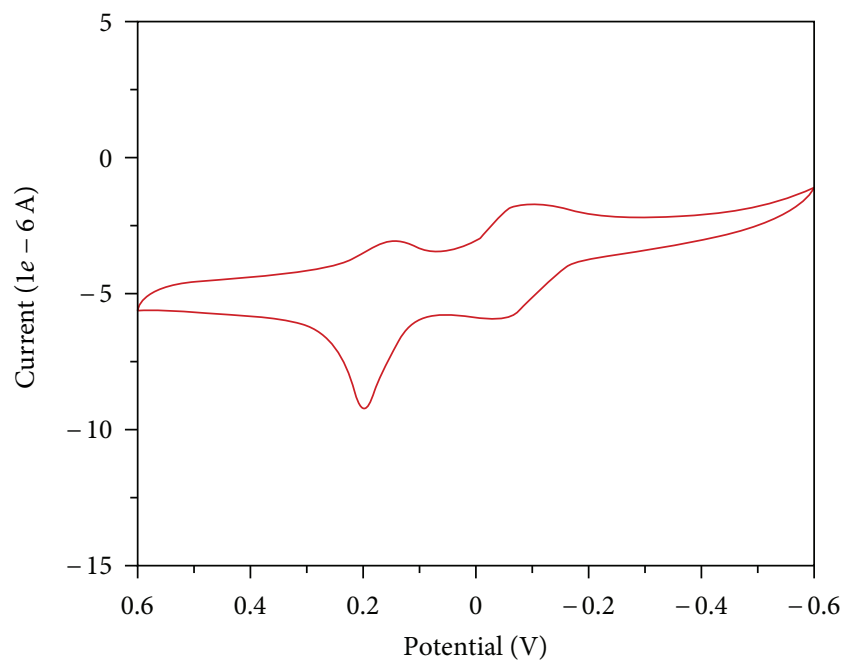

FIgURE 6: The cyclic voltammetry of the $\mathrm{CuL}_{2}$ complex.

$(F) \rightarrow{ }^{3} T_{1 g}(F)$ and ${ }^{3} A_{2 g}(F) \rightarrow{ }^{3} T_{1 g}(P)$ transitions, respectively, being characteristic of an octahedral geometry supported by its magnetic susceptibility value $(2.97 \mu \mathrm{B})$. The cobalt complex indicates three absorption bands at 17789, 16457, and $11477 \mathrm{~cm}^{-1}$, which are assigned as ${ }^{4} T_{1 g}(F) \rightarrow$ ${ }^{4} T_{2 g}(F),{ }^{4} T_{1 g}(F) \rightarrow{ }^{4} A_{2 g}(F)$ and ${ }^{4} T_{1 g}(F) \rightarrow{ }^{4} T_{1 g}(F)$ transitions, respectively. The band at $11467 \mathrm{~cm}^{-1}$ confirms the octahedral geometry, which is also supported by its magnetic susceptibility value $(4.38 \mu \mathrm{B})$ [30-32].

3.6. Cyclic Voltammetry. Cyclic voltammetry is the most popular technique for studying electrochemical reactions. The cyclic voltammogram of the $\mathrm{CuL}_{2}$ complex in DMSO solution (from 0.6 to $-0.6 \mathrm{~V}$ potential range) shows a well defined redox active corresponding to the formation of the $\mathrm{Cu}(\mathrm{II}) / \mathrm{Cu}(\mathrm{III})$ couple at $E_{\mathrm{pa}}=0.197 \mathrm{~V}$ and the associated anodic peak at $E_{\mathrm{pc}}=0.152 \mathrm{~V}$ (Figure 6). This couple found to be reversible with $\Delta E_{p}=0.04 \mathrm{~V}$ and the ratio of anodic to cathodic peak currents $\left(I_{\mathrm{pc}} / I_{\mathrm{pa}}=1\right)$ corresponding to 


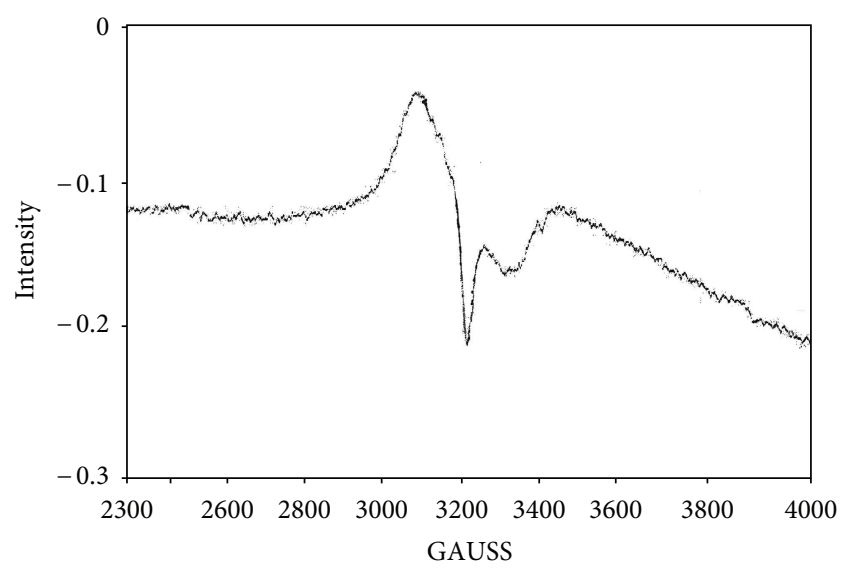

FIGURE 7: ESR spectrum of copper complex at Room Temperature.

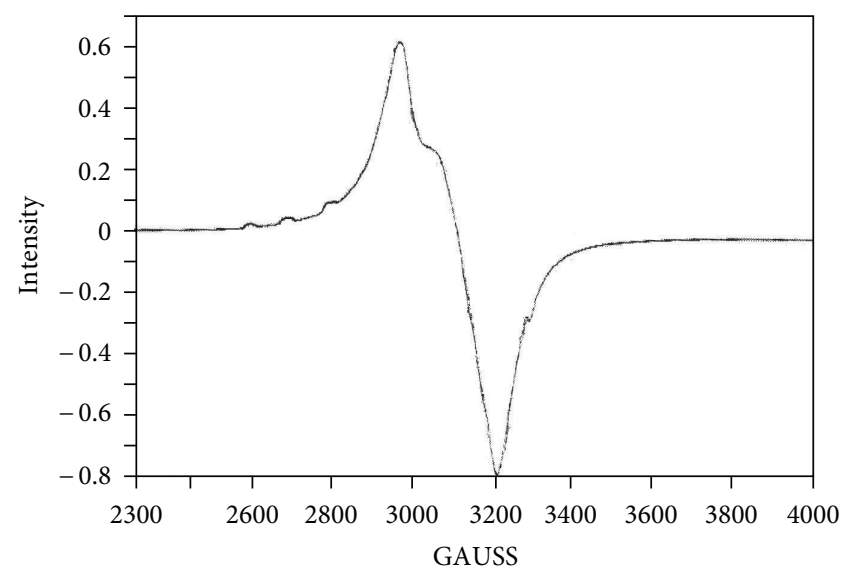

FIGURE 8: ESR spectrum of copper complex at liquid nitrogen temperature.

a simple to one-electron process. The complex also shows a reversible peak in the negative region characteristic of the $\mathrm{Cu}(\mathrm{II}) \rightarrow \mathrm{Cu}(\mathrm{I})$ couple at $E_{\mathrm{pc}}=-0.082 \mathrm{~V}$ with the associated anodic peak at $E_{\mathrm{pa}}=-0.076 \mathrm{~V}$ for $\mathrm{Cu}(\mathrm{I}) \rightarrow \mathrm{Cu}(\mathrm{II})$ oxidation.

3.7. EPR Spectra. The EPR spectrum of copper complex provides information, important in studying the metal ion environment. The EPR spectra were recorded in DMSO at RT (room temperature) and LNT (liquid nitrogen temperature) (Figures 7 and 8). The spectrum of the copper complex at RT showed one intense absorption band in the high field and was isotropic due to the tumbling motion of the molecules. However, this complex at LNT showed well resolved peaks with low field region. The copper complex exhibited the $g$ value of 2.36 and $g$ value of 2.08. These values indicate that the $\mathrm{Cu}$ (II) lies predominantly in the $d_{x^{2}-y^{2}}$ orbital, as was evident from the value of the exchange interaction term $G$, estimated from the expression:

$$
G=g_{\|}-\frac{2.0023}{g_{\perp}}-2.0023
$$

TABLE 2: Shape complementarity score of DNA-Metal complexes.

\begin{tabular}{lcc}
\hline S. No & Metal Complexes & Shape-Complementarity score \\
\hline$(1)$ & DNA-CoL $_{2}$ & 4032 \\
$(2)$ & DNA-CuL $_{2}$ & 3724 \\
$(3)$ & DNA-NiL $_{2}$ & 3884 \\
$(4)$ & DNA-ZnL $_{2}$ & 4122 \\
\hline
\end{tabular}

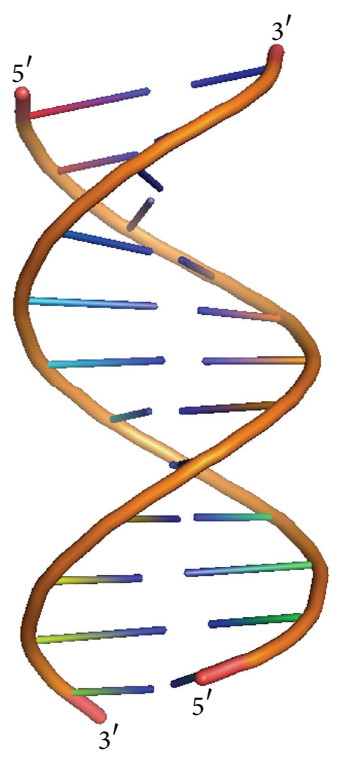

FIGURE 9: Structure of DNA Molecule (Display: PyMol).

It is reported that $g_{\|}$is 2.4 for copper-oxygen bonds, 2.3 for copper-nitrogen bonds. For mixed copper-nitrogen and copper-oxygen systems, there is a small difference in the point of symmetry from octahedral geometry [33]. For the present copper complex, the $g_{\|}$value (2.36) is between 2.3-2.4. This shows that the complex contains mixed coppernitrogen and copper-oxygen bonds. If $G>4.0$, the local tetragonal axes are aligned parallel or only slightly misaligned. If $G<4.0$, significant exchange coupling is present and the misalignment is appreciable. The observed value for the exchange interaction parameter for the copper complex $(G=4.5)$ suggests that the local tetragonal axes are aligned parallel or slightly misaligned, and the unpaired electron is present in the orbital. This result also indicates that the exchange coupling effects are not operative in the present complex [34].

3.8. In Silico DNA-Metal Complex Interaction. The structure of DNA is displayed in Figure 9. The Patch dock web server [23] was used to study the interaction between DNA and metal complexes. One hundred docking conformations were generated for each metal complex with its DNA molecule. For each docking results, the best solution was inferred by highest value of shape complementarity score (Table 2). The shape-complementarity score of four complexes was computed using Patch dock web server [23] and the results 
TABLE 3: Inter-molecular hydrogen bonds present in DNA-CoL ${ }_{2}$.

\begin{tabular}{|c|c|c|c|c|c|c|c|}
\hline Type & Donor & Donor atom & Acceptor & Acceptor atom & $d(\mathrm{H} \cdots \mathrm{A})(\AA)$ & $D(\mathrm{X} \cdots \mathrm{A})(\AA)$ & $q(\mathrm{X}-\mathrm{H} \cdots \mathrm{A})\left({ }^{\circ}\right)$ \\
\hline $\mathrm{C}-\mathrm{H} \cdots \mathrm{N}$ & $\mathrm{CoL}_{2}$ & $\mathrm{C}$ & Adenine & N6 & 2.068 & 3.054 & 148.8 \\
\hline $\mathrm{C}-\mathrm{H} \cdots \mathrm{N}$ & $\mathrm{CoL}_{2}$ & $\mathrm{C}$ & Adenine & N6 & 2.251 & 3.160 & 139.1 \\
\hline $\mathrm{C}-\mathrm{H} \cdots \mathrm{N}$ & $\mathrm{CoL}_{2}$ & $\mathrm{C}$ & Adenine & N7 & 1.307 & 1.749 & 93.07 \\
\hline $\mathrm{C}-\mathrm{H} \cdots \mathrm{N}$ & $\mathrm{CoL}_{2}$ & $\mathrm{C}$ & Adenine & N6 & 2.473 & 3.121 & 118.6 \\
\hline $\mathrm{C}-\mathrm{H} \cdots \mathrm{N}$ & $\mathrm{CoL}_{2}$ & $\mathrm{C}$ & Adenine & N7 & 2.273 & 3.103 & 133.8 \\
\hline $\mathrm{C}-\mathrm{H} \cdots \mathrm{O}$ & $\mathrm{CoL}_{2}$ & $\mathrm{C}$ & Adenine & $\mathrm{O} 2 \mathrm{P}$ & 2.640 & 3.656 & 154.6 \\
\hline $\mathrm{C}-\mathrm{H} \cdots \mathrm{O}$ & $\mathrm{CoL}_{2}$ & $\mathrm{O}$ & Adenine & $\mathrm{O} 2 \mathrm{P}$ & 2.943 & 3.191 & 96.02 \\
\hline $\mathrm{C}-\mathrm{H} \cdots \mathrm{O}$ & $\mathrm{CoL}_{2}$ & $\mathrm{C}$ & Adenine & $\mathrm{O} 1 \mathrm{P}$ & 1.253 & 1.934 & 113.2 \\
\hline $\mathrm{C}-\mathrm{H} \cdots \mathrm{O}$ & $\mathrm{CoL}_{2}$ & $\mathrm{C}$ & Guanine & $\mathrm{O} 2 \mathrm{P}$ & 1.390 & 2.013 & 109.7 \\
\hline $\mathrm{C}-\mathrm{H} \cdots \mathrm{O}$ & $\mathrm{CoL}_{2}$ & $\mathrm{C}$ & Thymine & $\mathrm{O} 4$ & 1.187 & 2.122 & 141.6 \\
\hline
\end{tabular}

TABLE 4: Inter-molecular hydrogen bonds present in $\mathrm{DNA}^{-\mathrm{CuL}_{2}}$.

\begin{tabular}{|c|c|c|c|c|c|c|c|}
\hline Type & Donor & Donor atom & Acceptor & Acceptor atom & $d(\mathrm{H} \cdots \mathrm{A})(\AA)$ & $D(\mathrm{X} \cdots \mathrm{A})(\AA)$ & $q(\mathrm{X}-\mathrm{H} \cdots \mathrm{A})\left({ }^{\circ}\right)$ \\
\hline $\mathrm{C}-\mathrm{H} \cdots \mathrm{O}$ & $\mathrm{CuL}_{2}$ & $\mathrm{C}$ & Thymine & O4 & 2.949 & 3.479 & 110 \\
\hline $\mathrm{C}-\mathrm{H} \cdots \mathrm{N}$ & $\mathrm{CuL}_{2}$ & $\mathrm{C}$ & Adenine & N7 & 2.859 & 3.657 & 129.7 \\
\hline $\mathrm{C}-\mathrm{H} \cdots \mathrm{N}$ & $\mathrm{CuL}_{2}$ & $\mathrm{C}$ & Adenine & N7 & 2.839 & 3.445 & 114.8 \\
\hline $\mathrm{C}-\mathrm{H} \cdots \mathrm{O}$ & $\mathrm{CuL}_{2}$ & $\mathrm{C}$ & Adenine & $\mathrm{O} 2 \mathrm{P}$ & 2.762 & 3.688 & 142.3 \\
\hline $\mathrm{C}-\mathrm{H} \cdots \mathrm{O}$ & $\mathrm{CuL}_{2}$ & $\mathrm{C}$ & Adenine & $\mathrm{O} 1 \mathrm{P}$ & 2.877 & 3.650 & 127.6 \\
\hline $\mathrm{C}-\mathrm{H} \cdots \mathrm{O}$ & $\mathrm{CuL}_{2}$ & $\mathrm{C}$ & Adenine & $\mathrm{O} 2 \mathrm{P}$ & 2.741 & 3.366 & 115.9 \\
\hline $\mathrm{C}-\mathrm{H} \cdots \mathrm{O}$ & $\mathrm{CuL}_{2}$ & $\mathrm{C}$ & Adenine & $\mathrm{O} 5$ & 2.459 & 3.351 & 170.3 \\
\hline $\mathrm{C}-\mathrm{H} \cdots \mathrm{N}$ & $\mathrm{CuL}_{2}$ & $\mathrm{C}$ & Adenine & N7 & 2.504 & 3.352 & 165.9 \\
\hline $\mathrm{C}-\mathrm{H} \cdots \mathrm{N}$ & $\mathrm{CuL}_{2}$ & $\mathrm{C}$ & Adenine & N6 & 2.328 & 2.926 & 114.1 \\
\hline $\mathrm{C}-\mathrm{H} \cdots \mathrm{N}$ & $\mathrm{CuL}_{2}$ & $\mathrm{C}$ & Adenine & N6 & 2.872 & 3.480 & 116.7 \\
\hline $\mathrm{C}-\mathrm{H} \cdots \mathrm{O}$ & $\mathrm{CuL}_{2}$ & $\mathrm{C}$ & Adenine & O1P & 2.597 & 2.939 & 98.01 \\
\hline $\mathrm{C}-\mathrm{H} \cdots \mathrm{N}$ & $\mathrm{CuL}_{2}$ & $\mathrm{C}$ & Adenine & N6 & 2.810 & 3.262 & 105.8 \\
\hline $\mathrm{C}-\mathrm{H} \cdots \mathrm{N}$ & $\mathrm{CuL}_{2}$ & $\mathrm{C}$ & Adenine & N7 & 2.203 & 3.015 & 132 \\
\hline $\mathrm{C}-\mathrm{H} \cdots \mathrm{N}$ & $\mathrm{CuL}_{2}$ & $\mathrm{C}$ & Adenine & N6 & 2.192 & 2.951 & 126.8 \\
\hline $\mathrm{C}-\mathrm{H} \cdots \mathrm{N}$ & $\mathrm{CuL}_{2}$ & $\mathrm{C}$ & Adenine & N6 & 2.709 & 2.935 & 91.53 \\
\hline $\mathrm{C}-\mathrm{H} \cdots \mathrm{O}$ & $\mathrm{CuL}_{2}$ & $\mathrm{C}$ & Adenine & $\mathrm{O} 1 \mathrm{P}$ & 2.445 & 2.861 & 102 \\
\hline
\end{tabular}

TABLE 5: Inter-molecular hydrogen bonds present in $\mathrm{DNA}^{-\mathrm{NiL}_{2}}$.

\begin{tabular}{|c|c|c|c|c|c|c|c|}
\hline Type & Donor & Donor atom & Acceptor & Acceptor atom & $d(\mathrm{H} \cdots \mathrm{A})(\AA)$ & $D(\mathrm{X} \cdots \mathrm{A})(\AA)$ & $q(\mathrm{X}-\mathrm{H} \cdots \mathrm{A})\left({ }^{\circ}\right)$ \\
\hline $\mathrm{C}-\mathrm{H} \cdots \mathrm{O}$ & $\mathrm{NiL}_{2}$ & $\mathrm{C}$ & Thymine & $\mathrm{O} 4$ & 2.943 & 3.760 & 131.6 \\
\hline $\mathrm{C}-\mathrm{H} \cdots \mathrm{O}$ & $\mathrm{NiL}_{2}$ & $\mathrm{C}$ & Adenine & $\mathrm{O} 2 \mathrm{P}$ & 2.899 & 3.651 & 126.1 \\
\hline $\mathrm{C}-\mathrm{H} \cdots \mathrm{O}$ & $\mathrm{NiL}_{2}$ & $\mathrm{O}$ & Guanine & O1P & 1.745 & 2.387 & 121.1 \\
\hline $\mathrm{C}-\mathrm{H} \cdots \mathrm{O}$ & $\mathrm{NiL}_{2}$ & $\mathrm{O}$ & Guanine & $\mathrm{O} 2 \mathrm{P}$ & 2.008 & 2.874 & 149.0 \\
\hline $\mathrm{C}-\mathrm{H} \cdots \mathrm{O}$ & $\mathrm{NiL}_{2}$ & $\mathrm{C}$ & Adenine & $\mathrm{O} 2 \mathrm{P}$ & 2.951 & 3.177 & 92.36 \\
\hline $\mathrm{C}-\mathrm{H} \cdots \mathrm{O}$ & $\mathrm{NiL}_{2}$ & $\mathrm{C}$ & Adenine & $\mathrm{O} 2 \mathrm{P}$ & 2.902 & 3.622 & 125.4 \\
\hline $\mathrm{C}-\mathrm{H} \cdots \mathrm{O}$ & $\mathrm{NiL}_{2}$ & $\mathrm{C}$ & Thymine & $\mathrm{O} 4$ & 2.343 & 2.963 & 115.7 \\
\hline $\mathrm{C}-\mathrm{H} \cdots \mathrm{O}$ & $\mathrm{NiL}_{2}$ & $\mathrm{C}$ & Guanine & $\mathrm{O} 2 \mathrm{P}$ & 1.755 & 2.692 & 144.8 \\
\hline $\mathrm{C}-\mathrm{H} \cdots \mathrm{O}$ & $\mathrm{NiL}_{2}$ & $\mathrm{C}$ & Adenine & $\mathrm{O} 2 \mathrm{P}$ & 2.880 & 3.115 & 92.68 \\
\hline $\mathrm{C}-\mathrm{H} \cdots \mathrm{O}$ & $\mathrm{NiL}_{2}$ & $\mathrm{C}$ & Thymine & $\mathrm{O} 4$ & 2.514 & 3.028 & 108.8 \\
\hline $\mathrm{C}-\mathrm{H} \cdots \mathrm{N}$ & $\mathrm{NiL}_{2}$ & $\mathrm{C}$ & Adenine & N6 & 2.885 & 3.905 & 161.5 \\
\hline
\end{tabular}


TABLE 6: Inter-molecular hydrogen bonds present in DNA- $\mathrm{ZnL}_{2}$.

\begin{tabular}{|c|c|c|c|c|c|c|c|}
\hline Type & Donor & Donor atom & Acceptor & Acceptor atom & $d(\mathrm{H} \cdots \mathrm{A})(\AA)$ & $D(\mathrm{X} \cdots \mathrm{A})(\AA)$ & $q(\mathrm{X}-\mathrm{H} \cdots \mathrm{A})\left(^{\circ}\right)$ \\
\hline $\mathrm{C}-\mathrm{H} \cdots \mathrm{N}$ & $\mathrm{ZnL}_{2}$ & $\mathrm{C}$ & Adenine & N6 & 2.437 & 3.450 & 153.6 \\
\hline $\mathrm{C}-\mathrm{H} \cdots \mathrm{N}$ & $\mathrm{ZnL}_{2}$ & $\mathrm{C}$ & Adenine & N7 & 2.711 & 3.471 & 126.2 \\
\hline $\mathrm{C}-\mathrm{H} \cdots \mathrm{N}$ & $\mathrm{ZnL}_{2}$ & $\mathrm{C}$ & Adenine & N7 & 2.619 & 2.960 & 97.09 \\
\hline $\mathrm{C}-\mathrm{H} \cdots \mathrm{N}$ & $\mathrm{ZnL}_{2}$ & $\mathrm{C}$ & Adenine & N6 & 2.646 & 3.433 & 128.3 \\
\hline $\mathrm{C}-\mathrm{H} \cdots \mathrm{N}$ & $\mathrm{ZnL}_{2}$ & $\mathrm{C}$ & Adenine & N7 & 2.444 & 2.960 & 107.0 \\
\hline $\mathrm{C}-\mathrm{H} \cdots \mathrm{O}$ & $\mathrm{ZnL}_{2}$ & $\mathrm{C}$ & Adenine & $\mathrm{O} 2 \mathrm{P}$ & 2.943 & 3.270 & 97.5 \\
\hline $\mathrm{C}-\mathrm{H} \cdots \mathrm{O}$ & $\mathrm{ZnL}_{2}$ & $\mathrm{C}$ & Adenine & $\mathrm{O} 2 \mathrm{P}$ & 2.853 & 3.270 & 102.5 \\
\hline $\mathrm{C}-\mathrm{H} \cdots \mathrm{O}$ & $\mathrm{ZnL}_{2}$ & $\mathrm{C}$ & Guanine & O5 & 2.982 & 3.802 & 134.6 \\
\hline $\mathrm{C}-\mathrm{H} \cdots \mathrm{O}$ & $\mathrm{ZnL}_{2}$ & $\mathrm{C}$ & Guanine & $\mathrm{O} 3$ & 2.790 & 3.539 & 127.6 \\
\hline $\mathrm{C}-\mathrm{H} \cdots \mathrm{O}$ & $\mathrm{ZnL}_{2}$ & $\mathrm{C}$ & Adenine & $\mathrm{O} 2 \mathrm{P}$ & 1.746 & 2.389 & 114.5 \\
\hline $\mathrm{C}-\mathrm{H} \cdots \mathrm{O}$ & $\mathrm{ZnL}_{2}$ & $\mathrm{C}$ & Thymine & $\mathrm{O} 4$ & 2.619 & 3.645 & 162.9 \\
\hline $\mathrm{C}-\mathrm{H} \cdots \mathrm{N}$ & $\mathrm{ZnL}_{2}$ & $\mathrm{C}$ & Adenine & N6 & 2.479 & 2.919 & 103.7 \\
\hline $\mathrm{C}-\mathrm{H} \cdots \mathrm{N}$ & $\mathrm{ZnL}_{2}$ & $\mathrm{C}$ & Adenine & N7 & 2.660 & 3.302 & 118.7 \\
\hline $\mathrm{C}-\mathrm{H} \cdots \mathrm{O}$ & $\mathrm{ZnL}_{2}$ & $\mathrm{C}$ & Thymine & $\mathrm{O} 4$ & 2.974 & 3.480 & 109.8 \\
\hline
\end{tabular}

TABLE 7: Statistics of inter-molecular hydrogen bonds present between DNA and metal complexes.

\begin{tabular}{lccccccccc}
\hline Metal complexes & $\mathrm{N}-\mathrm{H} \cdots \mathrm{O}$ & $\mathrm{O}-\mathrm{H} \cdots \mathrm{O}$ & $\mathrm{N}-\mathrm{H} \cdots \mathrm{N}$ & $\mathrm{O}-\mathrm{H} \cdots \mathrm{N}$ & $\mathrm{C}-\mathrm{H} \cdots \mathrm{O}$ & $\mathrm{C}-\mathrm{H} \cdots \mathrm{N}$ & $\mathrm{N}-\mathrm{H} \cdots \mathrm{S}$ & $\mathrm{O}-\mathrm{H} \cdots \mathrm{S}$ & $\mathrm{C}-\mathrm{H} \cdots \mathrm{S}$ \\
\hline DNA-CoL & 0 & 0 & 0 & 0 & 5 & 5 & 0 & 0 \\
DNA-Cu L & 0 & 0 & 0 & 0 & 7 & 9 & 0 & 0 \\
DNA-NiL $_{2}$ & 0 & 0 & 0 & 0 & 10 & 1 & 0 & 0 \\
DNA-Zn L $_{2}$ & 0 & 0 & 0 & 0 & 7 & 7 & 0 & 0 \\
\hline
\end{tabular}

reveal that DNA with $\mathrm{Cu}$-complex posses the lowest shapecomplementarity score compared to other three complexes. From the molecular docking results (Figure 10), the best solution was selected and it was processed into HBAT [25] or Hydrogen Bond Analysis Tool for computing the possible inter-molecular hydrogen bonds present between DNA and metal complexes. HBAT [25] results explain that two intermolecular $\mathrm{C}-\mathrm{H} \cdots \mathrm{O}$ and $\mathrm{C}-\mathrm{H} \cdots \mathrm{N}$ hydrogen bonds played a crucial role for the stability all metal complexes with DNA. The details of inter-molecular $\mathrm{C}-\mathrm{H} \cdots \mathrm{O}$ and $\mathrm{C}-\mathrm{H} \cdots \mathrm{N}$ interactions were given in Tables 3-6. However, in all four complexes did not contain other inter-molecular hydrogen bonds such as $\mathrm{N}-\mathrm{H} \cdots \mathrm{O}, \mathrm{O}-\mathrm{H} \cdots \mathrm{O}, \mathrm{N}-\mathrm{H} \cdots \mathrm{N}, \mathrm{O}-\mathrm{H} \cdots \mathrm{N}, \mathrm{N}-\mathrm{H} \cdots \mathrm{S}$, $\mathrm{O}-\mathrm{H} \cdots \mathrm{S}, \mathrm{C}-\mathrm{H} \cdots \mathrm{S}, \mathrm{C}-\mathrm{H} \cdots \pi, \mathrm{N}-\mathrm{H} \cdots \pi$ and $\mathrm{O}-\mathrm{H} \cdots \pi$. Figure 11 and Table 7 explains the statistics of various possible weak inter-molecular hydrogen bonds present between DNA and metal complexes.

In order to understand the stability of metal complex with DNA, we have used two parameters such as "shape complementary score" and "number of inter-molecular hydrogen bonds". Patch dock and HBAT analysis results suggested that the interaction between DNA and $\mathrm{Cu}$-complex is more stable (Low shape complementarity score and more number of weak intermolecular hydrogen bonds) rather than others. All the four complexes are binding to "Major groove" portion of DNA and hence they are called as "Major groove binders".
3.9. Antimicrobial Activity. Standard antibacterial agents were used for the comparative studies. The disc concentration levels are under National Committee for Clinical Laboratory Standards (NCCLS) column. The results of the antibacterial agents were given in the Table 8 . From this data, it has been found that all the compounds showed various significant inhibitory activity $[35,36]$ against five MTCC human pathogenic of microbial species namely $S$. aureus, B. subtilis, $P$. aeruginosa, $P$. vulgaris and $C$. albicans. The antibacterial activity of the tested compounds some of may have dose dependent and it may found to be good activity at 40 and $60 \mu \mathrm{L}$ concentrations.

\section{Conclusion}

A new series of transition metal complexes were synthesized from the Schiff base ligand derived from 4aminoantipyrine, 4-hydroxy-3-methoxybenzaldehyde and 2aminophenol. The structural features were derived from their elemental analyses, Mass spectroscopy, IR, UV-vis, NMR, ESR spectral analyses and conductivity measurements. Cyclic voltammogram of copper complex in DMSO show well defined quasi-reversible one electron transfer process corresponding to the formation of the couple. The data of the complexes suggested an octahedral geometry for the metal complexes. The results of in silico DNA-metal complex 


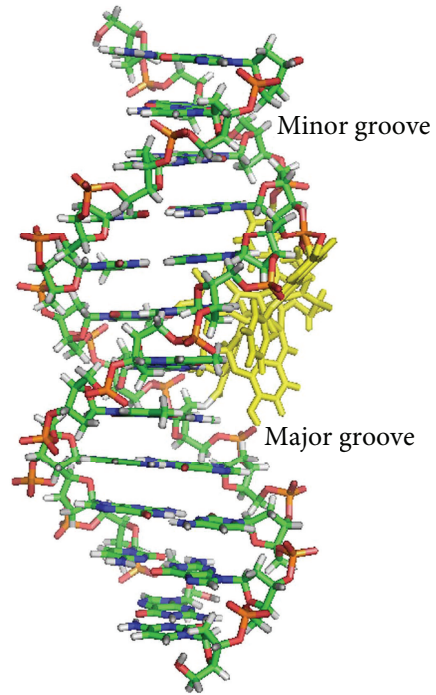

(a)

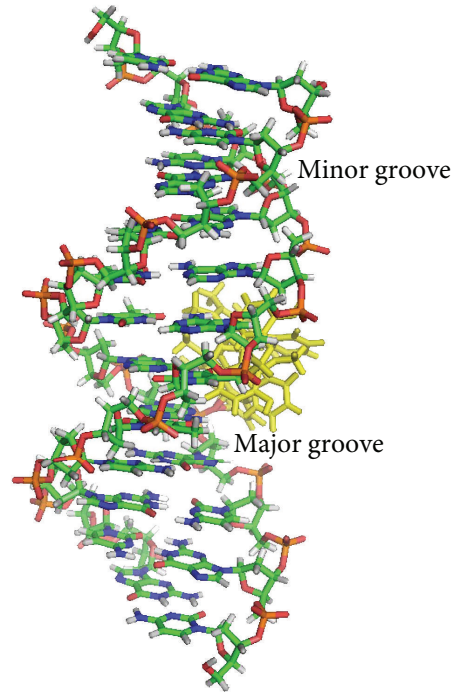

(b)

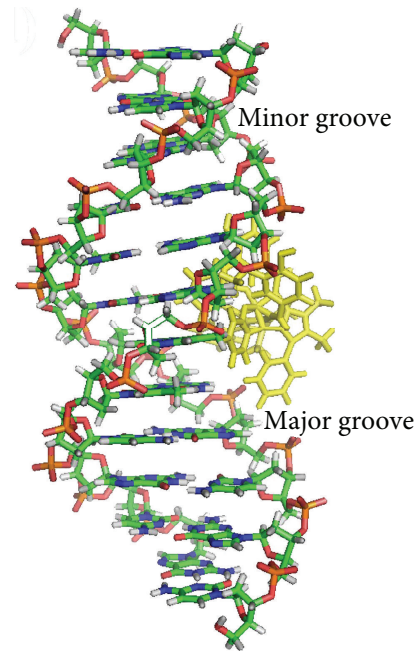

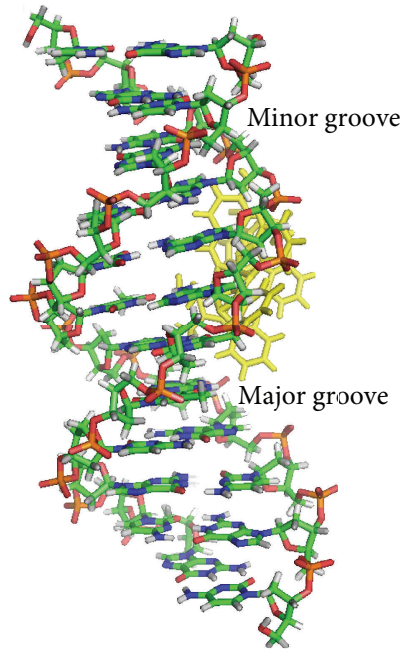

(c)

(d)

Figure 10: Molecular docking results DNA-metal complex interaction (a) DNA-CoL 2 , (b) DNA-CuL 2 , (c) DNA-NiL and $(d)$ DNA-ZnL $_{2}$ complex. [Color codes: Ligand: Yellow, Representation: Stick, Display: PyMol].

TABLE 8: Antimicrobial activity data for the Schiff base and their metal complexes.

\begin{tabular}{|c|c|c|c|c|c|c|c|c|c|c|c|c|}
\hline \multirow{2}{*}{ Compounds } & \multicolumn{3}{|c|}{ B. subtilis } & \multicolumn{3}{|c|}{ S. aureus } & \multicolumn{3}{|c|}{ P. vulgaris } & \multicolumn{3}{|c|}{ C. albicans } \\
\hline & $20 \mu \mathrm{L}$ & $40 \mu \mathrm{L}$ & $60 \mu \mathrm{L}$ & $20 \mu \mathrm{L}$ & $40 \mu \mathrm{L}$ & $60 \mu \mathrm{L}$ & $20 \mu \mathrm{L}$ & $40 \mu \mathrm{L}$ & $60 \mu \mathrm{L}$ & $20 \mu \mathrm{L}$ & $40 \mu \mathrm{L}$ & $60 \mu \mathrm{L}$ \\
\hline $\mathrm{HL}$ & 10 & 12 & 14 & 11 & 13 & 18 & - & - & 9 & 12 & 14 & 15 \\
\hline $\mathrm{CuL}_{2}$ & - & 10 & 11 & 8 & 11 & 12 & 10 & 11 & 13 & 9 & 12 & 13 \\
\hline $\mathrm{NiL}_{2}$ & 9 & 13 & 15 & 9 & 14 & 16 & - & 9 & 11 & 9 & 13 & 15 \\
\hline $\mathrm{CoL}_{2}$ & 10 & 11 & 13 & 8 & 12 & 13 & 10 & 12 & 14 & 9 & 11 & 13 \\
\hline $\mathrm{ZnL}_{2}$ & 10 & 12 & 15 & 8 & 13 & 15 & 10 & 12 & 14 & 9 & 12 & 14 \\
\hline Tetracycline (Antibacterial agent) & 14 & 19 & 23 & 13 & 16 & 21 & 15 & 18 & 24 & - & - & - \\
\hline Amphotericin (Antifungal agent) & - & - & - & - & - & - & - & - & - & 15 & 19 & 21 \\
\hline
\end{tabular}

Zone of inhibition (diameter in $\mathrm{mm}$ ). 


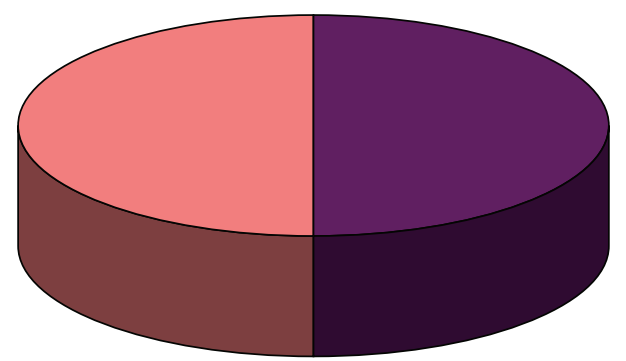

(a) DNA-Co complex
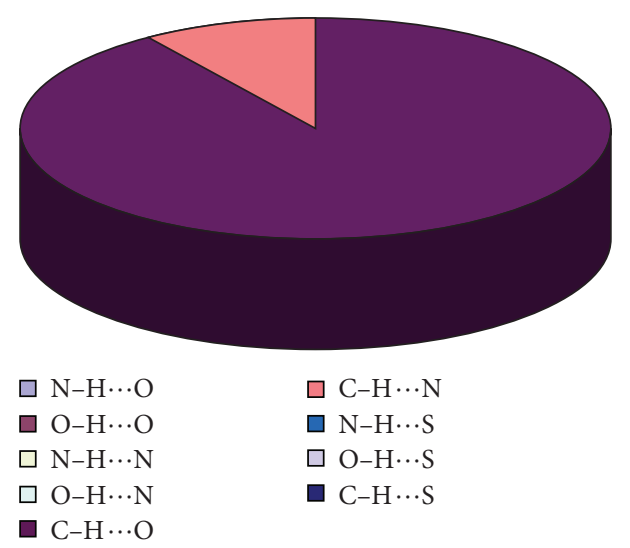

(c) DNA-No complex

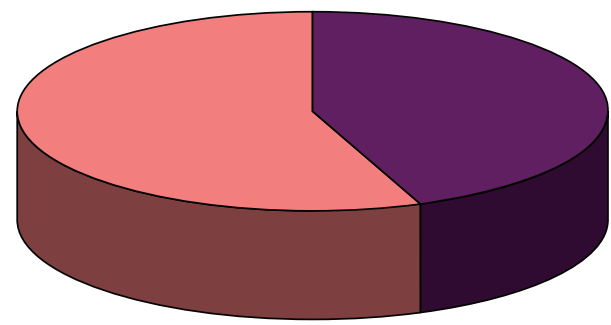

(b) DNA-Cu complex
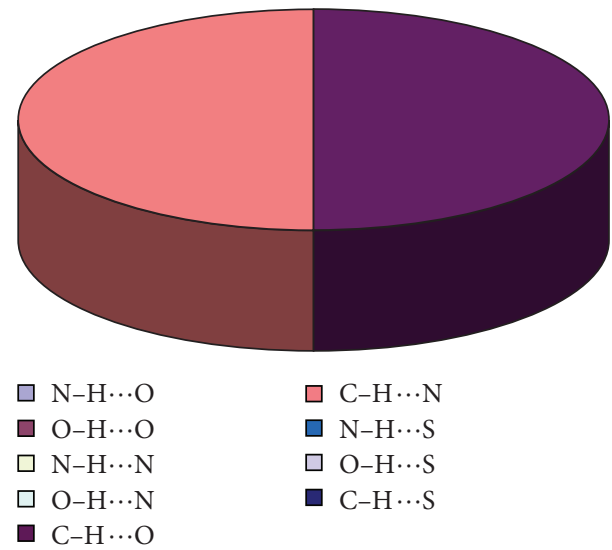
complexes with 2-(N-salicylideneamino)-3-carboxyethyl-4,5dimethylthiophene," Spectrochimica Acta Part A, vol. 70, no. 2, pp. 403-410, 2008.

[12] G. G. Mohamed, M. M. Omar, and A. Ibrahim, "Biological activity studies on metal complexes of novel tridentate Schiff base ligand. Spectroscopic and thermal characterization," European Journal of Medicinal Chemistry, vol. 44, no. 12, pp. 4801-4812, 2009.

[13] S. Chandra, D. Jain, A. K. Sharma, and P. Sharma, "Coordination modes of a Schiff base pentadentate derivative of 4-aminoantipyrine with cobalt(II), nickel(II) and copper(II) metal ions: synthesis, spectroscopic and antimicrobial studies," Molecules, vol. 14, no. 1, pp. 174-190, 2009.

[14] G. S. Kurdekar, M. P. Sathisha, S. Budagumpi, N. V. Kulkarni, V. K. Revankar, and D. K. Suresh, "4-Aminoantipyrine-based Schiff-base transition metal complexes as potent anticonvulsant agents," Medicinal Chemistry Research. In press.

[15] N. Raman, N. Selvan, and P. Manisankar, "Spectral, magnetic, biocidal screening, DNA binding and photocleavage studies of mononuclear $\mathrm{Cu}$ (II) and $\mathrm{Zn}$ (II) metal complexes of tricoordinate heterocyclic Schiff base ligands of pyrazolone and semicarbazide/thiosemicarbazide based derivatives," Spectrochimica Acta Part A, vol. 76, no. 2, pp. 161-173, 2010.

[16] Y. K. Vaghasiya, R. Nair, M. Soni, S. Baluja, and S. Chanda, "Synthesis, structural determination and antibacterial activity of compounds derived from vanillin and 4-aminoantipyrine," Journal of the Serbian Chemical Society, vol. 69, no. 12, pp. 991-998, 2004.

[17] N. Raman and S. Sobha, "Exploring the DNA binding mode of transition metal based biologically active compounds," Spectrochimica Acta Part A, vol. 85, no. 1, pp. 223-234, 2011.

[18] N. Raman, S. Sobha, and A. Thamaraichelvan, "A novel bioactive tyramine derived Schiff base and its transition metal complexes as selective DNA binding agents," Spectrochimica Acta Part A, vol. 78, no. 2, pp. 888-898, 2010.

[19] http://www.scfbio-iitd.res.in/software/drugdesign/bdna.jsp.

[20] S. Arnott, P. J. Campbell-Smith, and R. Chandrasekaran, "Atomic coordinates and molecular conformations for DNADNA, RNA-RNA, and DNA-RNA helices," in Handbook of Biochemistry and Molecular Biology, G. P. Fasman, Ed., vol. 2 of Nucleic Acids, pp. 411-422, CRC Press, Cleveland, Ohio, USA, 3rd edition, 1976.

[21] http://www.cambridgesoft.com/software/ChemDraw/.

[22] Accelrys Software Inc, Discovery Studio Modeling Environment, Release 3.1, Accelrys Software Inc, San Diego, Calif, USA, 2012.

[23] D. Schneidman-Duhovny, Y. Inbar, R. Nussinov, and H. J. Wolfson, "PatchDock and SymmDock: servers for rigid and symmetric docking," Nucleic Acids Research, vol. 33, no. 2, pp. W363-W367, 2005.

[24] http://www.pymol.org/.

[25] A. Tiwari and S. K. Panigrahi, "HBAT: a complete package for analysing strong and weak hydrogen bonds in macromolecular crystal structures," In Silico Biology, vol. 7, no. 6, pp. 651-661, 2007.

[26] A. H. Al-Kubaisi and K. Z. Ismail, "Nickel(II) and palladium(II) chelates of dehydroacetic acid Schiff bases derived from thiosemicarbazide and hydrazinecarbodithioate," Canadian Journal of Chemistry, vol. 72, no. 8, pp. 1785-1788, 1994.

[27] A. El-Dissouky, "Metal complexes of 4,5-dimethylpyrazole3-carboxaldehyde phenylthiosemicarbazone," Spectrochimica Acta Part A, vol. 43, no. 9, pp. 1177-1182, 1987.
[28] M. F. Iskander, L. Ei-Syed, and K. Z. Ismail, Transition Metal Chemistry, vol. 4, p. 225, 1979.

[29] M. Thomas, M. K. M. Nair, and R. K. Radhakrishan, "Rare earth iodide complexes of 4-(2',4'-Dihydroxyphenylazo) antipyrine," Synthesis and Reactivity in Inorganic and Metal-Organic Chemistry, vol. 25, no. 3, pp. 471-479, 1995.

[30] A. B. P. Lever, Inorganic Electronic Spectroscopy, Elsevier, New York, NY, USA, 1968.

[31] L. N. Sharada and M. C. Ganorkar, Indian Journal of Chemistry, vol. 27, p. 617, 1988.

[32] R. L. Duta and A. Syamal, Elements of Magnetochemistry, East West Press, New Delhi, India, 1992.

[33] M. Massacesi, G. Ponticelli, V. B. Addepali, and V. G. Krishnan, "Anion and symmetry effects on the ESR spectra of copper complexes, part I," Journal of Molecular Structure, vol. 51, pp. 27-36, 1979.

[34] A. M. F. Benial, V. Ramakrishnan, and R. Murugesan, "Single crystal EPR of $\mathrm{Cu}\left(\mathrm{C}_{5} \mathrm{H}_{5} \mathrm{NO}\right)_{6}\left(\mathrm{BF}_{4}\right)_{2}$ : an example of admixed ground state," Spectrochimica Acta, vol. 56, no. 14, pp. 2775-2781, 2000.

[35] G. G. Mohamed, M. A. Zayed, and S. M. Abdallah, "Metal complexes of a novel Schiff base derived from sulphametrole and varelaldehyde. Synthesis, spectral, thermal characterization and biological activity," Journal of Molecular Structure, vol. 979, no. 1-3, pp. 62-71, 2010.

[36] A. Abdel Aziz Ayman, M. Salem Abdel Naby, A. Sayed Mostafa, and M. Aboaly Mohamed, "Synthesis, structural characterization, thermal studies, catalytic efficiency and antimicrobial activity of some $\mathrm{M}$ (II) complexes with ONO tridentate Schiff base N-salicylidene-o-aminophenol $\left(\mathrm{saphH}_{2}\right)$," Journal of Molecular Structure, vol. 1010, pp. 130-138, 2012. 

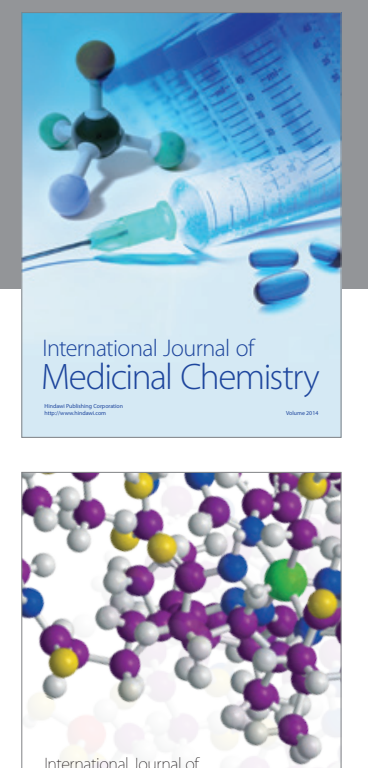

\section{Carbohydrate} Chemistry

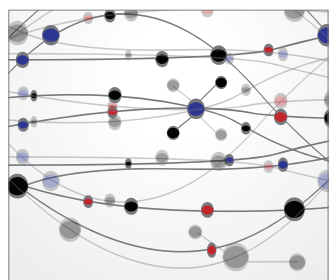

The Scientific World Journal
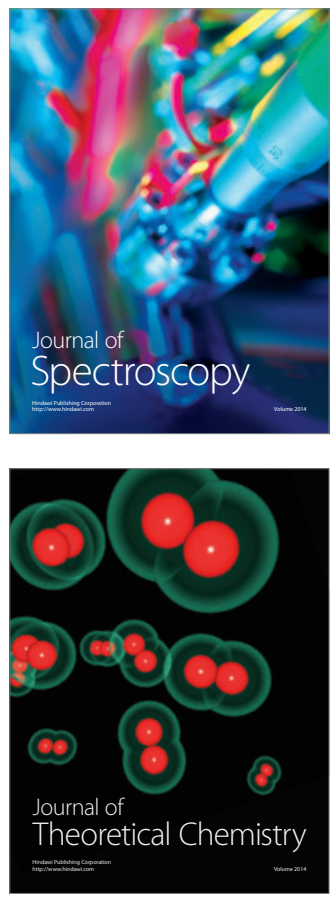
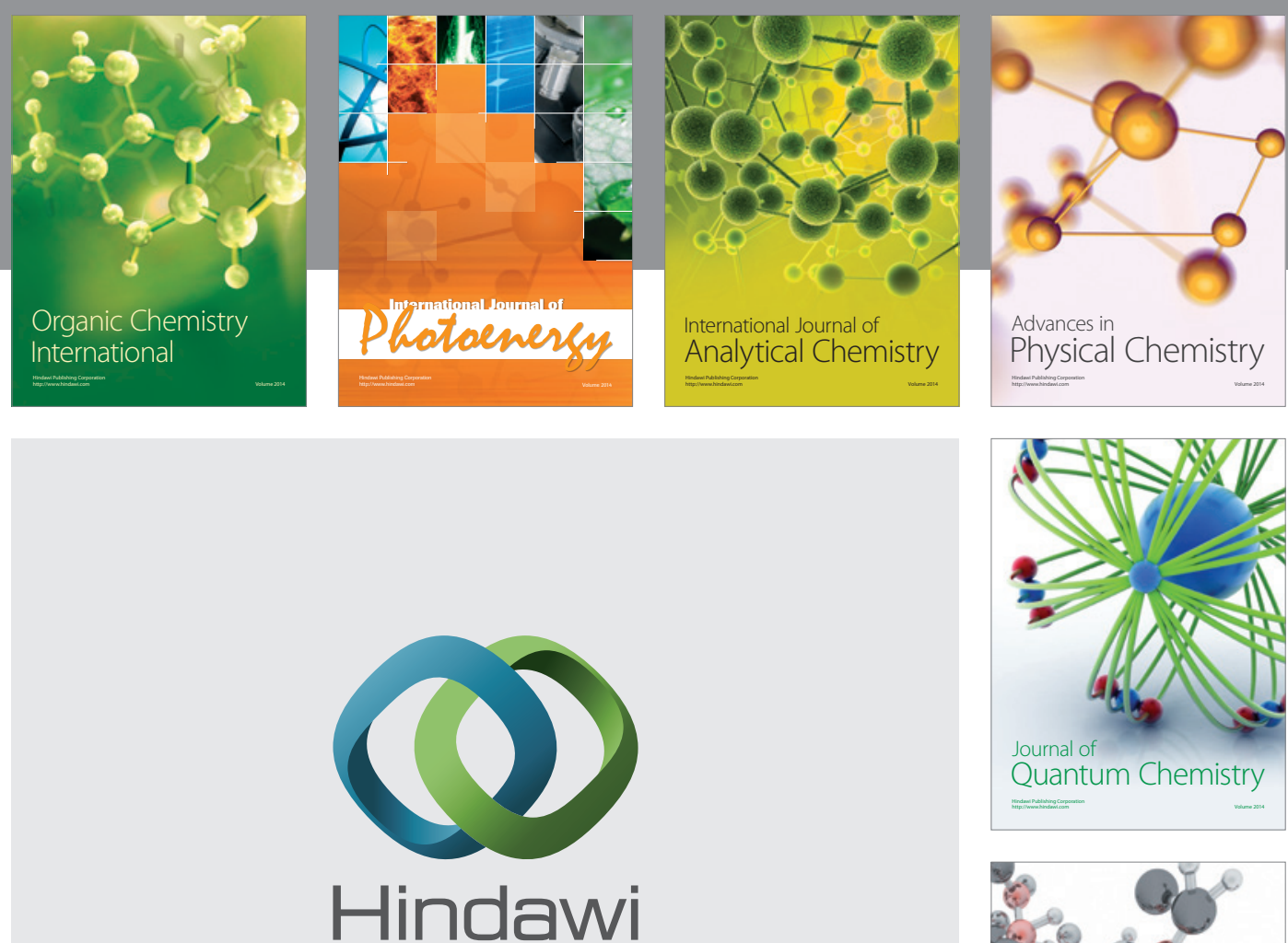

Submit your manuscripts at

http://www.hindawi.com

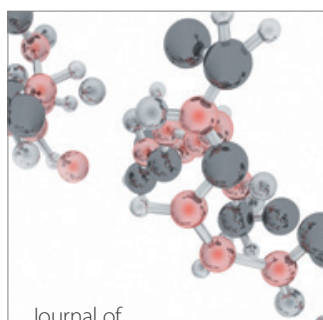

Analytical Methods

in Chemistry

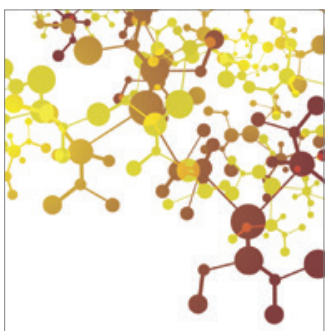

Journal of

Applied Chemistry

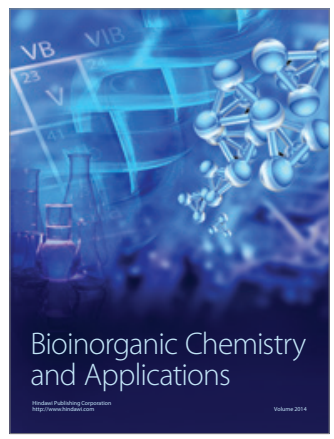

Inorganic Chemistry
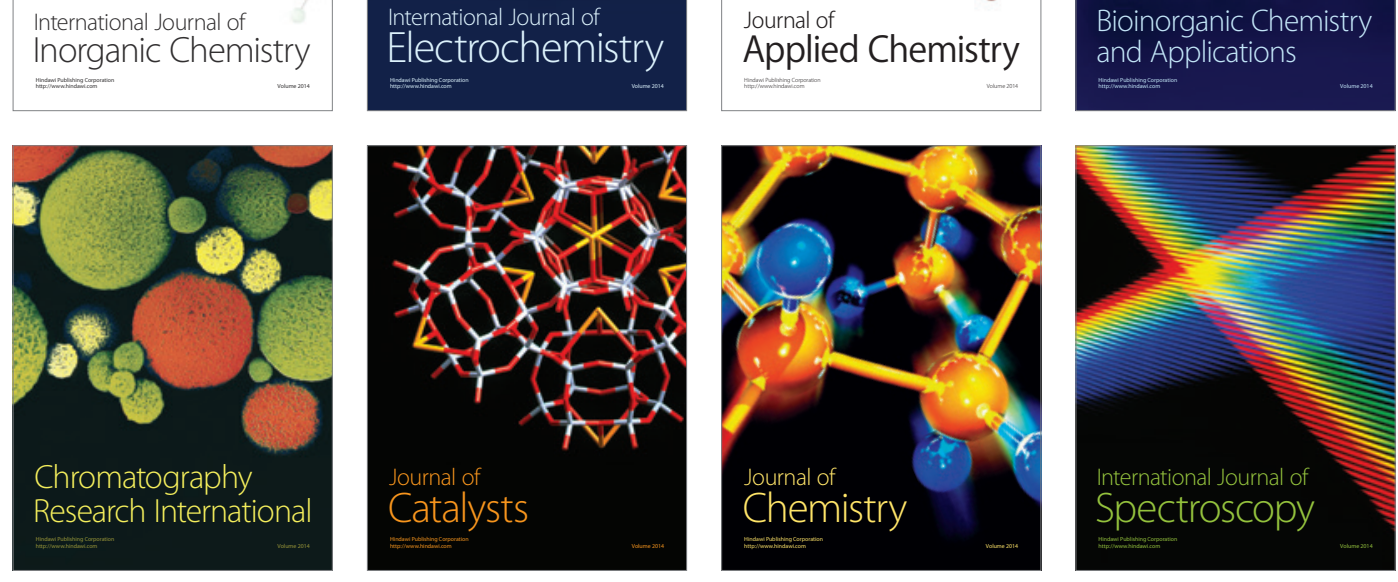